\title{
Editorial
}

\section{The deconstruction of financial risk}

Journal of Banking Regulation (2007) 9, 1-2. doi:10.1057/palgrave.jbr.2350060

George Walker reviews some of the principal background trends and changes that have taken place in modern financial markets and the challenges that these have created in terms of financial stability and central bank function.

All of the recent crises in US sub-prime lending, inter-bank markets, Northern Rock and most recent support operations announced by the Bank of England reflect certain more fundamental changes that have been taking place in national and international financial markets over the last two to three decades.

A substantial amount of credit has moved from being bank to security based as part of a larger process of 'securitisation' in many markets. Banks specifically have been 'disintermediated' in many cases with borrowers issuing their own debt through short-term commercial paper programmes or with securitised debt being sold into the market through special-purpose vehicles (SPVs) set up to support underlying securitisation programmes. A number of new types of financial instruments and vehicles have been created especially with SPVs and the separate growth in structured products including collateralised mortgage obligations (CMOs), collateralised loan obligations (CLOs) and credit linked notes (CLNs) as well as other collateralised debt obligations (CDOs).

Financial derivatives are now considered 'old' (having originated in the early 1970s) although derivatives and, in particular, credit derivatives are now often used for 'repackaging' purposes and frequently embedded into new financial instruments creating considerably more complex 'structured' products. There has also been a parallel process of 'privatisation' (in addition to disintermediation) of debt with the issuance and trading of debt through private placements, off-market 'introductions' or OTC markets rather than with full listing and formal public issues. This has, in particular, arisen as a result of the growth in the disposal or conversion of many public corporations into private companies and especially with the expansion of the private equity market which began in the 1970 s but grew substantially during the late 1980s, 1990s and early 2000s.

All of this (securitisation, disintermediation, financial innovation and repacking as well as privatisation of debt) has been associated with a further 'deconstruction' of risk within financial markets. This has involved exposures (including, in particular, credit risk) being broken up (or 'layered'), assigned a credit rating by a rating agency (often paid by the institution issuing the debt which practice is now being examined by the European Commission) and then sold off in separate security-based 'tranches'. The effect of this has been to distribute risk over a much wider category of investors (including hedge funds and other new investment vehicles such as SIVs and off-balance sheet bank conduits).

Financial risk has then been divided up and distributed across the financial system in a much wider, less transparent and more complex manner than ever before. The original and direct management of risk by banks and other financial intermediaries has also been replaced by market rating and trading. Investors will often only purchase products with a view to selling them on to generate profit but also to avoid having to hold them to maturity and bear the loss for any outstanding or residual market or credit risk concerned. Original and 
immediate risk management has then been replaced by risk separation, risk division and risk trading.

The effect of all of this has been to make the role of the central bank as the protector of monetary and financial stability considerably more complex than before. Central banks still have to discharge their two parallel functions of managing monetary policy (the cost and volume of money and credit in circulation) and the stability of the financial systems (including the payment and settlements infrastructure). The main problem is simply that as more liquidity is injected for immediate support purposes, this may undermine longer term monetary management and inflation strategies. Some commentators have already claimed that these two roles may have become more confused with the recent Federal Reserve and ECB interventions. This may then have become further confused with the most recent Treasury interventions in the UK in support of Northern Rock and the UK banking system as a whole.

With these processes of securitisation, disintermediation, repacking, privatisation and deconstruction of risk (as well as the associated separation of risk management and risk trading referred to), central banks will now have to act as more general providers of liquidity to the financial system on a more substantial and continuing basis. This does form part of their general money market management function although the nature and extent of this may have changed significantly in light of recent events.

The financial system must be protected from significant crisis or collapse, although the proper nature and limits of this function appear to have become increasingly confused in recent weeks and months. The central bank must manage monetary and financial stability together while the authorities must avoid providing support (and bail out) to careless borrowers or reckless, irresponsible or unscrupulous lenders more generally. How all of this will be achieved remains to be seen. Many complex and difficult decisions may lie ahead before this crisis is fully resolved.

George Walker

Professor in International Financial Law at the Centre for Commercial Law Studies, Queen Mary, London 